\title{
DINAMIKA GURU DALAM MENGHADAPI MEDIA PEMBELAJARAN TEKNOLOGI INFORMASI DAN KOMUNIKASI
}

\author{
Nabil \\ STIT Al Marhalah Al Ulya Bekasi \\ Email:anisbata124@gmail.com
}

\begin{abstract}
Teknologi informasi dan komunikasi dewasa ini sudah menjadi bagian dari gaya hidup masyarakat Indonesia, kemajuannya yang begitu pesat telah merambah ke dunia pendidikan. Kondisi ini dapat dilihat dari banyaknya lembaga-lemabaga pendidikan yang terus tumbuh dan berkembang yang menerapkan media pembelajaran berbasis teknologi.

Media pembelajaran adalah media yang digunakan dalam pembelajaran, yaitu meliputi alat bantu guru dalam mengajar serta sarana pembawa pesan dari sumber belajar ke penerima pesan belajar (siswa). Sebagai penyaji dan penyalur pesan, media belajar dalam hal-hal tertentu bisa mewakili guru menyajikan informasi belajar kepada siswa. Jika program media itu didesain dan dikembangkan secara baik, maka fungsi itu akan dapat diperankan oleh media meskipun tanpa keberadaan guru.

Peranan media yang semakin meningkat sering menimbulkan kekhawatiran pada guru. Namun sebenarnya hal itu tidak perlu terjadi, masih banyak tugas guru yang lain seperti: memberikan perhatian dan bimbingan secara individual kepada siswa yang selama ini kurang mendapat perhatian. Kondisi ini akan terus terjadi selama guru menganggap dirinya merupakan sumber belajar satu-satunya bagi siswa. Jika guru memanfaatkan berbagai media pembelajaran secara baik, guru dapat berbagi peran dengan media. Peran guru akan lebih mengarah sebagai manajer pembelajaran dan bertanggung jawab menciptakan kondisi sedemikian rupa agar siswa dapat belajar. Untuk itu guru lebih berfungsi sebagai penasehat, pembimbing, motivator dan fasilitator dalam kegiatan belajar mengajar.
\end{abstract}

Kata Kunci : Teknologi Informasi, Peran Guru, Media Pembelajaran, dan Komunikasi dalam Belajar Mengajar 


\section{Pendahuluan}

Perkembangan masyarakat dunia pada umumnya dan masyarakat Indonesia pada khususnya sudah memasuki masyarakat informasi yang merupakan kelanjutan dari masyarakat modern dengan ciri-cirinya bersifat rasional, berorientasi kepada masa depan, terbuka, menghargai waktu, kreatif, mandiri, dan inovatif. Dengan adanya perubahan tersebut dunia pendidikan saat ini telah ikut mengalami kemajuan dalam penggunaan berbagai media pembelajaran yang bertujuan memberikan pemahaman kepada peserta didik.

Media pembelajaran merupakan salah satu komponen pembelajaran yang mempunyai peranan penting dalam kegiatan belajar mengajar. Pemanfaatan media seharusnya merupakan bagian yang harus mendapat perhatian guru/fasilitator dalam setiap kegiatan pembelajaran. Oleh karena itu guru/fasilitator perlu mempelajari bagaimana menetapkan media pembelajaran agar dapat mengefektifkan pencapaian tujuan pembelajaran dalam proses belajar mengajar.

Revolusi ilmu pengetahuan dan teknologi, perubahan masyarakat, pemahaman cara belajar anak, kemajuan media komunikasi dan informasi dan lain sebagainya memberi arti tersendiri bagi kegiatan pendidikan. Tantangan tersebut menjadi salah satu dasar pentingnya pendekatan teknologis dalam pengelolaan pendidikan.

Teknologi secara subtantif telah menjadi bagian integral dalam kehidupan manusia sejak zaman dahulu. Pada zaman batu sekalipun, teknologi telah menyertai sisi kehidupan manusia, misalnya dalam pembangunan piramida, candi, pembuatan api dan sebagainya. Seiring perjalanan dan peradaban manusia yang terus berubah, teknologi yang dikembangkan dan digunakan oleh manusia pun semakin canggih dan kompleks.

Teknologi merupakan hasil rekayasa manusia yang dicipta-kembangkan untuk mengatasi masalah dan atau keterbatasan manusia. Untuk memenuhi kebutuhan akan makan, dan lain sebagainya manusia menciptakan suatu teknologi.

Dalam bidang pendidikan, secara sadar atau tidak teknologi juga telah menjadi bagian integral. Penggunaan peraga indera dalam pembelajaran, merupakam fakta empiris yang merepresentasikan betapa teknologi menjadi bagian tak terpisahkan dalam sejarah perkembangan pendidikan.

Media pembelajaran adalah media yang digunakan dalam pembelajaran, yaitu meliputi alat bantu guru dalam mengajar serta sarana pembawa pesan dari sumber belajar ke penerima pesan belajar (siswa). Sebagai penyaji dan penyalur pesan, media belajar dalam hal-hal tertentu bisa mewakili guru menyajikan informasi belajar kepada siswa. Jika program media itu didesain dan dikembangkan secara baik, maka fungsi itu akan dapat diperankan oleh media meskipun tanpa keberadaan guru.

Peranan media yang semakin meningkat sering menimbulkan kekhawatiran pada guru. Namun sebenarnya hal itu tidak perlu terjadi, masih banyak tugas guru yang lain seperti: memberikan perhatian dan bimbingan secara individual kepada siswa yang selama ini kurang mendapat perhatian. Kondisi ini akan terus terjadi selama guru menganggap dirinya merupakan sumber belajar satu-satunya bagi siswa. Jika guru memanfaatkan berbagai media pembelajaran secara baik, guru dapat berbagi peran dengan media. Peran guru akan lebih mengarah sebagai manajer pembelajaran dan bertanggung jawab menciptakan kondisi sedemikian rupa agar siswa dapat belajar. Untuk itu guru lebih berfungsi sebagai penasehat, pembimbing, motivator dan fasilitator dalam kegiatan belajar mengajar. 
Perkembangan teknologi informasi dan komunikasi (TIK) telah memberikan pengaruh terhadap dunia pendidikan khususnya dalam proses pembelajaran. Menurut Rosenberg sebagaimana dikutif oleh Hamzah B. Uno bahwa dengan berkembangnya penggunaan TIK ada lima pergeseran dalam proses pembelajaran yaitu: (1) dari pelatihan ke penampilan, (2) dari ruang kelas ke di mana dan kapan saja, (3) dari kertas ke "on line" atau saluran, (4) fasilitas fisik ke fasilitas jaringan kerja, (5) dari waktu siklus ke waktu nyata.

Komunikasi sebagai media pendidikan dilakukan dengan menggunakan media-media komunikasi seperti telepon, komputer, internet, e-mail, dsb. Interaksi antara guru dan siswa tidak hanya dilakukan melalui hubungan tatap muka tetapi juga dilakukan dengan menggunakan media-media tersebut. Guru dapat memberikan layanan tanpa harus berhadapan langsung dengan siswa. Demikian pula siswa dapat memperoleh informasi dalam lingkup yang luas dari berbagai sumber melalui cyber space atau ruang maya dengan menggunakan komputer atau internet. Hal yang paling mutakhir adalah berkembangnya apa yang disebut "cyber teaching" atau pengajaran maya, yaitu proses pengajaran yang dilakukan dengan menggunakan internet. Istilah lain yang makin poluper saat ini ialah e-learning yaitu satu model pembelajaran dengan menggunakan media teknologi komunikasi dan informasi khususnya internet. Dalam kehidupan sehari-hari, peserta didik banyak dihadapkan pada aneka ragam jenis dan produk teknologi, baik yang dijumpai, dimanfaatkan, dialami, maupun yang dinikmati. Menghadapi kondisi seperti itu, peserta didik dijenjang pendidikan dasar perlu diarahkan dan dibekali pendidikan teknologi guna menuju masyarakat yang "melek teknologi" yaitu bercirikan mampu mengenal, mengerti, memilih, menggunakan, memelihara, memperbaiki, menilai, menghasilkan produk teknologi sederhana, dan peduli terhadap masalah yang berkaitan dengan teknologi. Tampak bahwa kehidupan manusia tidak terlepas dari adanya teknologi. Artinya, teknologi merupakan keseluruhan cara yang secara rasional mengarah pada ciri efisiensi dalam setiap kegiatan manusia. Seseorang menggunakan teknologi karena manusia berakal. Dengan akalnya untuk menyelesaikan setiap masalah, ingin hidup lebih baik, lebih mudah, lebih aman, dan lain sebagainya.

Dalam proses pembelajaran, media telah dikenal sebagai alat bantu mengajar yang seharusnya dimanfaatkan oleh pengajar, namun kadangkala terabaikan. Tidak dimanfaatkannya media dalam proses pembelajaran, pada umumnya disebabkan oleh berbagai alasan, seperti waktu persiapan mengajar terbatas, sulit mencari media yang tepat, biaya yang tidak tersedia, atau alasan lain. Hal tersebut sebenarnya tidak perlu muncul apabila pengetahuan akan ragam media, karakteristik, serta kemampuan masing-masing diketahui oleh para pengajar. Media sebagai alat bantu mengajar, berkembang sedemikian pesatnya sesuai dengan kemajuan teknologi. Ragam dan jenis media pun cukup banyak sehingga dapat dimanfaatkan sesuai dengan kondisi, waktu, keuangan, maupun materi yang akan disampaikan. Setiap jenis media memiliki karakteristik dan kemampuan dalam menayangkan pesan dan informasi.

Ada tiga hal penting yang harus dipikirkan ulang terkait dengan modernisasi pendidikan: (1) bagaimana kita belajar (how people learn); (2) apa yang kita pelajari (what people learn); dan (3) kapan dan dimana kita belajar (where and when people learn). Dengan mencermati jawaban atas ketiga pertanyaan ini, dan potensi IT yang bisa dimanfaatkan seperti telah diuraikan sebelumnya, maka peran IT dalam moderninasi pendidikan bangsa dapat dirumuskan. 
Peranan yang bisa dilakukan teknologi informasi dalam model pembelajaran ini sangat jelas. Hadirnya e-learning dengan semua variasi tingkatannya telah memfasilitasi perubahan ini. Secara umum, e-learning dapat didefinisikan sebagai pembelajaran yang disampaikan melalui semua media elektronik termasuk, Internet, intranet, extranet, satelit, audio/video tape, TV interaktif. E-learning telah mendorong demokratisasi pengajaran dan proses pembelajaran dengan memberikan kendali yang lebih besar dalam pembelajaran kepada siswa. Hal ini sangat sesuai dengan prinsip penyelenggaraan pendidikan nasional seperti termaktub dalam Pasal 4 ayat 1 Undang-Undang Nomor 20 Tahun 2003 tentang Sistem Pendidikan Nasional yang menyatakan bahwa "Pendidikan diselenggarakan secara demokratis dan berkeadilan serta tidak diskriminatif dengan menjunjung tinggi hak asasi manusia, nilai keagamaan, nilai kultural, dan kemajemukan bangsa".

Pentingnya pendekatan teknologis dalam pengelolaan tersebut dimaksudkan agar dapat membantu proses pendidikan dalam pencapaian tujuan pendidikan, yakni al-insani al-kamil. Di samping itu, pendidikan sebagi bagian dari kebudayaan merupakan sarana penerus nilai-nilai dan gagasan-gagasan sehingga setiap orang mampu berperan serta dalam transformasi nilai demi kemajaun bangsa dan negara. Oleh karena itu untuk mewujudkan pendidikan yang berkualitas, salah satu yang harus ada adalah guru yang berkualitas. Guru yang berkualitas ini adalah guru yang memiliki kemampuan untuk mewujudkan tujuan pendidikan nasional sebagaimana yang tercantum dalam UU Sisdiknas RI no. 14 tahun 2005 pasal 1 ayat 1dijelaskan,

"Guru adalah pendidik professional dengan tugas utama mendidik, mengajar, membimbing, mengarahkan, melatih, menilai, dan mengevaluasi peserta didik pada pendidikan anak usia dini jalur pendidikan formal pendidikan dasar, dan pendidikan menengah.

Terkait dengan pembelajaran, tuntutan abad 21 menuntut perubahan reorientasi dalam pembelajaran yaitu dari; (1). menggeser paradigma pembelajaran dari 'asumsi tersembunyi' bahwa pengetahuan dapat dipindahkan secara utuh dari 'otak/pikiran' guru ke 'otak/pikiran' siswa, menuju pembelajaran yang lebih 'memberdayakan' seluruh aspek kemampuan siswa. (2). menggeser paradigma pembelajaran dari berpusat pada guru (teacher centred learning) menuju pembelajaran yang berpusat pada siswa (student centred learning), belajar mandiri (self directed learning), dan pemahaman diri (metakognisi) karena pembelajaran ini dirasa lebih memberdayakan siswa dalam segala aspek. (3). menggeser dari belajar 'menghafal' konsep menuju belajar 'menemukan' dan 'membangun' (mengkonstruksi) sendiri konsep, yang terbukti mampu meningkatkan kemampuan siswa dalam berpikir tingkat tinggi, kritis, kreatif dan terampil memecahkan masalah, (4). menggeser dari belajar individual klasikal menuju pembelajaran kelompok kooperatif yang tidak hanya mengajari ketrampilan berpikir saja namun juga mampu mengajari siswa ketrampilan-ketrampilan lainnya (keterampilan sosial).

Misalnya, dalam melaksanakan kompetensi pedagogik, guru dituntut memiliki kemampuan secara metodologis dalam hal perancangan dan pelaksanaan pembelajaran. Termasuk didalamnya penguasaan dalam penggunaan media pembelajaran.

Penggunaan media atau alat bantu disadari oleh banyak praktisi pendidikan sangat membantu aktivitas proses pembelajaran baik didalam maupun di luar kelas, 
terutama membantu peningkatan prestasi belajar siswa. Namun dalam implementasinya tidak banyak guru yang memanfaatkannya, bahkan penggunaan metode ceramah (lecture method) monoton masih cukup popular dikalangan guru dalam proses pembelajarannya.

Teknologi Informasi dan Komunikasi (TIK) memilliki tiga fungsi utama yang digunakan dalam kegiatan pembelajaran, yaitu: (1) Teknologi berfungsi sebagai alat (tools), dalam hal ini TIK digunakan sebagai alat bantu bagi pengguna (user) atau siswa untuk membantu pembelajaran, misalnya dalam mengolah kata, mengolah angka, membuat unsur grafis, membuat database, membuat program administratif untuk siswa, guru dan staf, data kepegawaian, keungan dan sebagainya. (2) Teknologi berfungsi sebagai ilmu pengetahuan (science). Dalam hal ini teknologi sebagai bagian dari disiplin ilmu yang harus dikuasai oleh siswa. Misalnya teknologi komputer dipelajari oleh beberapa jurusan di perguruan tinggi seperti informatika, manajemen informasi, ilmu komputer. dalam pembelajaran di sekolah sesuai kurikulum 2006 terdapat mata pelajaran TIK sebagai ilmu pengetahuan yang harus dikuasi siswa semua kompetensinya. (3) Teknologi berfungsi sebagai bahan dan alat bantu untuk pembelajaran (literacy). Dalam hal ini teknologi dimaknai sebagai bahan pembelajaran sekaligus sebagai alat bantu untuk menguasai sebuah kompetensi berbantuan komputer. Madrasah Tsanawiyah Negeri (MTSN) 01 Kota Bekasi merupakan salah satu lembaga pendidikan yang bertempat di KH. Agus Salim Bekasi, yang telah menerapkan media teknologi dan informasi dalam kegiatan proses pembelajaran sudah menggunakan media berbasis Teknologi Informasi (IT).

\section{Guru dan Teknologi Media Pembelajaran}

Dalam kamus besar bahasa Indonesia, "Guru adalah orang yang pekerjaannya (mata pencahariannya, profesinya) mengajar". ${ }^{1}$ Pengertian ini memang dipandang terlalu sempit dimana hanya seorang yang pekerjaannya mengajar maka ia di sebut guru.

Menurut Benaldi Sutadipura yang dikutif oleh Syafrudin Nurdin dan Basyirudin Usman dalam bukunya yang berjudul Guru Profesional dan Implementasi Kurikulum mengatakan, "Guru adalah orang yang layak digugu dan ditiru. $^{2}$ Pengertian ini menjadi paradigma masyarakat mengenai guru bahwa seorang guru menjadi panutan bagi siswa dalam segala hal dan seorang guru harus mampunyai harga diri yang tinggi dan mempunyai kecerdasan intelegensi, emosional, dan spiritual.

Dalam Undang-Undang No. 20 Tahun 2003 tentang Sistem Pedidikan Nasional memberikan pengertian guru adalah pendidik yang mempunyai tugas mengajar, membimbing dan melatih anak didik. Pengertian ini mengarah pada profesionalisasi tugas keguruan, bahwa guru merupakan pengajar, pembimbing dan pelatih anak didik. Guru tidak hanya sebatas memberikan dan mentransfer ilmu pengetahuan, akan tetapi lebih dari itu adalah mendidik agar anak agar mampu menjadi orang yang bertanggung jawab terhadap diri sendiri dan lingkungannya.

Guru dalam Islam adalah orang yang bertanggung jawab terhadap perkembangan anak didik dengan mengupayakan seluruh potensinya, baik potensi afektif, potensi kognitif, maupun potensi psikomotorik. Guru juga berarti orang

\footnotetext{
${ }^{1}$ Depdiknas, Kamus Besar Bahasa Indonesia, (Jakarta : Balai Pustaka, 2001), h. 213

${ }^{2}$ Syafrudin dan Basyirudin Usman, Guru Profesional dan Implementasi Kurikulum, (Jakarta: Ciputat Pres, 2002), h. 7
} 
yang dewasa bertanggung jawab memberikan pertolongan pada anak didik dalam perkembangan jasmani dan rohaninya agar mencapai tingkat kedewasaan serta mampu berdiri sendiri dalam memenuhi tugasnya sebagai hamba Allah.

Dalam bahasa Arab istilah yang mengacu kepada pengertian guru lebih banyak seperti al 'alim (jamaknya 'ulama) atau al-mu'allim, yang berarti orang yang mengetahui dan banyak digunakan para ulama/ahli pendidikan untuk menunjuk kepada guru. ${ }^{3}$ Ada sebagian ulama yang menggunakan istilah almudarris untuk arti orang yang mengajar, atau orang yang memberikan pelajaran, namun dibandingkan dengan kata al-mu'allim adalah ulama dengan kata almudarris, ternyata penggunaan kata al-mu'allim adalah al-'alim lebih banyak dari penggunaan kata al-mudarris

\section{Media Pembelajaran}

Secara harfiah media diartikan sebagai "perantara" atau "pengantar" AECT mendefinisikan media yaitu segala bentuk yang digunakan untuk proses penyaluran informasi. ${ }^{4}$ Robert Hanick dan kawan-kawan menjelaskan bahwa media adalah sesuatu yang membawa informasi antara sumber (source) dan penerima (receiver) informasi. Masih dalam sudut yang sama Kempt dan Dayton mengemukakan peran media dalam proses komunikasi. ${ }^{5}$

Media berasal dari bahasa latin yang mempunyai arti :antara. Makna tersebut dapat diartikan sebagai alat komunikasi yang digunakan untuk membawa suatu informasi dari suatu sumber kepada penerima. ${ }^{6}$ Media juga merupakan bentuk jamak dari "Medium" yang secara harfiah berarti "perantara" atau "pengantar" yaitu perantara atau pengantar sumber pesan dengan penerima pesan. ${ }^{7}$ Kata media sebagai perantara atau pengantar terjadinya komunikasi dari pengirim menuju penerima. Media merupakan salah satu komponen komunikasi, yaitu sebagai pembawa pesan dari komunikator menuju komunikan. Berdasarkan definisi tersebut, dapat dikatakan bahwa proses pembelajaran merupakan proses komunikasi. Proses pembelajaran mengandung lima komponen komunikasi, guru (komunikator), bahan pembelajaran, media pembelajaran, siswa (komunikan), dan tujuan pembelajaran. Jadi, media pembelajaran adalah segala sesuatu yang dapat digunakan untuk menyalurkan pesan (bahan pembelajaran), sehingga dapat merangsang perhatian, minat, pikiran, dan perasaan siswa dalam kegiatan belajar untuk mencapai tujuan belajar. ${ }^{8}$

Oleh karena itu proses pembelajaran merupakan proses komunikasi dan berlangsung dalam suatu sistem, maka media pembelajaran menempati posisi yang cukup penting sebagai salah satu komponen sistem pembelajaran. Tanpa media, komunikasi tidak akan terjadi dan proses pembelajaran sebagai proses komunikasi juga tidak akan bisa berlangsung secara optimal. Media pembelajaran adalah komponen integral dari sistem pembelajaran.

3 Abuddin Nata, Perspektif Islam Tentang Pola Hubungan Guru-Murid Study Pemikiran Tasawuf al-Ghazali, (Jakarta: PT Raja Grafindo Persada, 2001), h. 41.

${ }^{4}$ Fatah Syukur, Teknologi Pendidikan, (Semarang: Rasail, 2004), h. 118

${ }^{5}$ Ibid., h. 118

${ }^{6}$ Hamzah. B. Uno, Profesi Kependidikan: Problema, Solusi, dan Reformasi Pendidikan di Indonesia, ( Jakarta: Bumi Aksara, 2009), h. 113 1984), h. 9

${ }^{7}$ Onong Uchyana Effendy, Ilmu Komunikasi Teori dan Praktek, ( Bandung: Rosdakarya,

${ }^{8}$ Ibid., h. 9 
Sejumlah pakar membuat batasan tentang media, diantaranya yang di kemukakan oleh Assocition of education and Communication Technology (AECT). Menurut AECT, media adalah segala bentuk dan saluran yang digunakan untuk menyalurkan pesan atau informasi. Apabila dikaitkan dengan kegiatan pembelajaran maka dapat diartikan sebagai alat komunikasi yang digunakan dalam proses pembelajaran untuk membawa informasi dari pengajar kepeserta didik. Hal yang sama juga dikemukan sebelumnya oleh Briggs, yang menyatakan bahwa media adalah segala bentuk fisik yang dapat meyampaikan pesan serta merangsang peserta didik untuk belajar. ${ }^{9}$

Dari batasan yang telah dikemukan para ahli mengenai media, dapat disimpulkan bahwa pengertian media dalam pembelajaran adalah segala bentuk alat komunikasi yang dapat digunakan untuk menyampaikan informasi yang dapat digunakan untuk menyampaikan informasi dari sumber ke peserta didik yang bertujuan merangsang mereka untuk mengikuti kegiatan pembelajaran.media juga digunakan untuk menyampaikan bagian tertentu dari kegiatan pembelajaran, memberikan penguatan motivasi.

\section{Komunikasi dalam Proses Belajar Mengajar}

Secara etimologis, komunikasi berasal dari kata to communicate. Menurut Longman Dictionary of Cotemporary English, definisi kata communicate adalah upaya untuk membuat pendapat, menyatakan perasaan, menyampaikan informasi dan sebagainya agar dapat diketahui atau dipahami oleh orang lain. Arti lain dari komunikasi adalah berbagi (to share) atau bertukar (to exchange) pendapat, perasaan, informasi dan sebagainya. ${ }^{10}$ Menurut Drs. H. Toto Tasmara dalam bukunya, Komunikasi Dakwah secara sederhana memberikan pengertian tentag komunikasi. Seseorang yang berkomunikasi berarti mengharapkan agar orang lain dalam hal ini yang diajak berkomunikasi untuk dapat ikut berpartisipasi atau tindakan sama sesuai dengan tujuan, harapan atau isi pesan yang disampaikan. Dengan penekanan bahwa komunikasi berarti upaya untuk mengadakan persamaan atau commonness dengan orang lain dengan cara menyampaikan keterangan, berupa suatu gagasan ataupun sikap. ${ }^{11}$

Kata atau istilah komunikasi (dari bahasa Inggris “communication”), secara etimologis atau menurut asal katanya adalah dari bahasa Latin communicatus, dan perkataan ini bersumber pada kata communis. Dalam kata communis ini memiliki makna 'berbagi' atau 'menjadi milik bersama yaitu suatu usaha yang memiliki tujuan untuk kebersamaan atau kesamaan makna.

Komunikasi secara terminologis merujuk pada adanya proses penyampaian suatu pernyataan oleh seseorang kepada orang lain. Jadi dalam pengertian ini yang terlibat dalam komunikasi adalah manusia. Bahwa komunikasi manusia adalah proses yang melibatkan individu-individu dalam suatu hubungan, kelompok, organisasi dan masyarakat yang merespon dan menciptakan pesan untuk beradaptasi dengan lingkungan satu sama lain. ${ }^{12}$

\footnotetext{
${ }^{9}$ Ibid., h. 114

${ }^{10}$ Bambang Warsita,, Teknologi Pembelajaran: Landasan dan Aplikasinya, (Jakarta: Rineka Cipta, 2009), h. 96

${ }^{11}$ Toto Tasmara, Komunikasi Dakwah, ( Jakarta: Media Pratama, 2005), h. 5

${ }^{12}$ Effendy, Onong Uchjana, Ilmu Komunikasi Teori dan Praktek, (Bandung: Rosdakarya,
} 2008), h. 9 
Dengan berkomunikasi sebenarnya mengharapkan atau bertujuan terjadinya perubahan sikap atau tingkah laku orang lain untuk memenuhi harapan sebagaimana pesan disampaikan. Perubahan sikap dan tingkah laku akibat dari proses komunikasi adalah perubahan sikap yang sesuai dengan apa yang diharapkan oleh komunikator. Dengan demikian apa yang disampaikan oleh komunikator pada komunikasi akan mempengaruhi sikap komunikan sejauh kemampuan komunikator dalam mempengaruhinya.

\section{Unsur Komunikasi}

Dalam proses komunikasi ada 5 unsur yaitu :

1. Komunikator (penyampai) adalah Orang yang menyampaikan pesan kepada komunikan.

2. Komunikan (penerima) adalah Orang yang menerima pesan dari Kominikator.

3. Pesan/informasi/berita yang disampaikan dari komunikator kepada komunikan.

4. Media adalah alat yang digunakan untuk menyampaikan pesan atau berita. ${ }^{13}$

5. Respon adalah tanggapan atau feedback yang diperoleh komunikator dari komunikan.

\section{Bentuk-bentuk Komunikasi}

Dalam kehidupan sehari-hari proses komunikasi terbagi menjadi 2 bagian, yakni komunikasi primer dan sekunder.

a. Proses komunikasi secara primer.

Adalah proses penyampaian pikiran dan atau perasaan seseorang kepada orang lain dengan menggunakan lambang (simbol) sebagai media. Lambang sebagai media primer dalam proses komunikasi adalah bahasa, isyarat, gambar, warna, dan lain sebagainya yang secara langsung mampu "menerjemahkan" pikiran dan atau perasaan komunikator kepada komunikan.

b. Proses komunikasi secara sekunder

Adalah proses penyampaian pesan oleh seseorang kepada orang lain dengan menggunakan alat atau sarana sebagai media kedua setelah memakai lambang sebagai media pertama. Seorang komunitaor menggunakan media kedua dalam melancarkan komunikasinya karena komunikan sebagai sasarannya berada ditempat yang relatif jauh, atau jumlahnya banyak, surat telepon, teleks, surat kabar, majalah, radio, televisi, film, dan banyak lagi adalah media kedua yang sering digunakan dalam komunikasi. Pada umumnya ketika berbicara dikalangan masyarakat, yang dinamakan media komunikasi itu adalah media kedua sebagai diterangkan di atas. ${ }^{14}$

\section{Jenis - Jenis Komunikasi}

Pada dasarnya komunikasi digunakan untuk menciptakan atau meningkatkan aktifitas hubungan antara manusia atau kelompok, jenis komunikasi terdiri dari :

1. Komunkasi verbal dengan lisan maupun tertulis

a. Vocabulary (perbendaharaan kata). komunikasi akan tidak efektif bila pesan disampaikan dengan kata-kata yang tidak dimengerti, karena itu olah kata menjadi penting dalam berkomuniksai.

b. Racing (kecepatan). Komunikasi akan lebih efektif dan sukses bila kecepatan bicara dapat diatur dengan baik, tidak terlalu cepat atau terlalu lambat.

\footnotetext{
${ }^{13}$ Ibid., h. 7

${ }^{14}$ Ibid., h. 15-16
} 
c. Intonasi suara, akan mempengaruhi arti pesan secara dramatik sehingga pesan akan menjadi lain artinya bila diucapkan dengan intonasi suara yang berbeda. Intonasi suara yang tidak proporsional merupakan hambatan dalam berkomunikasi.

d. Humor, dapat meningkatkan kehidupan yang bahagia. Tertawa dapat membantu menghilangkan strees dan nyeri. tertawa mempunyai hubungan fisik dan psikis dan harus diingat bahwa humor adalah merupakan satu-satunya selingan dalam berkomunikasi.

e. Singakat dan jelas, komunikasi akan efektif bila disampaikan secara singkat dan jelas langsung pada pokok permasalahannya sehingga lebih mudah dimengerti.

f. Timing (waktu yang tepat), adalah hal kritis yang perlu diperhatikan karena berkomunikasi akan berarti bila seseorang bersedia untuk berkomunikasi, artinya dapat menyediakan waktu untuk mendengarkan atau memperlihatkan apa yang disampaikan.

2. Komunikasi non verbal dengan gerakan-gerakan tubuh (bahasa tubuh). Komunikasi non verbal adalah penyampaian pesan tanpa kata-kata dan komunikasi non verbal memberikan arti pada komunikasi verbal. Yang termasuk komunikasi non verbal :

a) Ekspresi wajah, wajah merupakan sumber yang kaya dengan komunikasi, karena ekspresi wajah cerminan suasana emosi seseorang.

b) Kontak mata, merupakan sinyal alamiah untuk berkomunikasi. Dengan mengadakan kontak mata selama berinterakasi atau tanya jawab berarti orang tersebut terlibat dan menghargai lawan bicaranya dengan kemauan untuk memperhatikan bukan sekedar mendengarkan. Melalui kontak mata juga memberikan kesempatan pada orang lain untuk mengobservasi yang lainnya.

c) Sentuhan adalah bentuk komunikasi personal mengingat sentuhan lebih bersifat spontan dari pada komunikasi verbal. Beberapa pesan seperti perhatian yang sungguh-sungguh, dukungan emosional, kasih sayang atau simpati dapat dilakukan melalui sentuhan.

d) Postur tubuh dan gaya berjalan. Cara seseorang berjalan, duduk, berdiri dan bergerak memperlihatkan ekspresi dirinya. Postur tubuh dan gaya berjalan merefleksikan emosi, konsep diri, dan tingkat kesehatannya.

e) Sound (Suara). Rintihan, menarik nafas panjang, tangisan juga salah satu ungkapan perasaan dan pikiran seseorang yang dapat dijadikan komunikasi. Bila dikombinasikan dengan semua bentuk komunikasi non verbal lainnya sampai desis atau suara dapat menjadi pesan yang sangat jelas.

f) Gerak isyarat, adalah yang dapat mempertegas pembicaraan. Menggunakan isyarat sebagai bagian total dari komunikasi seperti mengetuk-ngetukan kaki atau mengerakkan tangan selama berbicara menunjukkan seseorang dalam keadaan stress bingung atau sebagai upaya untuk menghilangkan stres. ${ }^{15}$

\section{Bentuk komunikasi berdasarkan besarnya sasaran :}

\footnotetext{
15 Jalaluludin Rakhmat, Psikologi Komunikasi, ( Bandung: Rosdakarya: 2008), h. 76
} 
1). Komunikasi massa, yaitu komunikasi dengan sasarannya kelompok orang dalam jumlah yang besar, umumnya tidak dikenal. Komunikasi masa yang baik harus :

- Pesan disusun dengan jelas, tidak rumit dan tidak bertele-tele

- Bahasa yang mudah dimengerti/dipahami.

- Bentuk gambar yang baik.

- Membentuk kelompok khusus, misalnya kelompok pendengar (radio).

2). Komunikasi kelompok Adalah komunikasi yang sasarannya sekelompok orang yang umumnya dapat dihitung dan dikenal dan merupakan komunikasi langsung dan timbal balik. Misalnya : Perawat--- Pengunjung pukesmas.

3). Komunikasi Perorangan adalah Komunikasi dengan tatap muka dapat juga melalui telepon misalnya: perawat--- pasien.

\section{Bentuk komunikasi berdasarkan arah pesan :}

a. Komunikasi satu arah; pesan disampaikan oleh sumber kepada sasaran dan sasaran tidak dapat atau tidak mempunyai kesempatan untuk memberikan umpan balik atau bertanya, dalam hal ini misalnya radio $A--->B$.

b. Komunikasi timbal balik; pesan disampaikan kepada sasaran dan sasaran memberikan umpan balik. Biasanya komunikasi kelompok atau perorangan merupakan komunikasi timbal balik.

\section{Tujuan berkomunikasi}

Onong Uchyana Effendy, menjabarkan tujuan penggunaan proses komunikasi secara spesifik sebagai berikut:

1. Mempelajari atau mengajarkan sesuatu

2. Mempengaruhi perilaku seseorang

3. Mengungkapkan perasaan

4. Menjelaskan perilaku sendiri atau perilaku orang lain

5. Berhubungan dengan orang lain

6. Menyelesaian sebuah masalah

7. Mencapai sebuah tujuan

8. Menurunkan ketegangan dan menyelesaian konflik

9. Menstimulasi minat pada diri sendiri atau orng lain. ${ }^{16}$ Agar komunikasi berlangsung efektif ada beberapa faktor yang harus dipenuhi meliputi: :

1. Credibility (keterpercayaan) Maksudnya antara komunikator dan komunikan terdapat rasa saling percaya.

2. Context (pertalian) Maksudnya komunikasi dapat terjadi kalau sikon setempat tidak ada gangguan antara komunikator dengan komunikan serta sarana/media komunikasi saling berkaitan.

3. Content (kepuasan) Artinya komunikator dapat menyampaikan pesan kepada komunikan dalam hal ini komunikan dapat memahami maksud komunikator sehingga komunikator merasa puas.

4. Clarity (kejelasan) Adalah komunikator harus menyampaikan pesan/berita secara jelas istilahnya pun harus jelas sehingga tercapainya tujuan.

5. Continuity and consistency (kesinambungan dan konsistensi) Artinya komunikasi berlangsung terus dan pesan/berita tidak saling bertentangan (tidak berubah-ubah/tetap)

\footnotetext{
${ }^{16}$ Onong Uchyana Effendy, Ilmu Komunikasi,: Sebuah Teori dan Praktek, h. 7
} 
6. Capability of Audience (kemampuan pihak penerima) Maksudnya komunikator harus memperhatikan kemampuan komunikan (pihak penerima) dalam menerima pesan, agar tidak terjadi kesalahfahaman.

7. Channels of Distribution (saluran penerimaan berita) Artinya komunikasi harus menggunakan media / alat komunikasi yang sudah biasa digunakan oleh umum, misalnya media cetak (surat kabar, majalah) media elektronik (telepon, televisi). ${ }^{17}$

\section{Fungsi Komunikasi}

Komunikasi berfungsi diantaranya sebagai berikut: ${ }^{18}$

a. Kendali : komunikasi bertindak untuk mengendalikan prilaku anggota dalam beberapa cara, setiap organisasi mempunyai wewenang dan garis panduan formal yang harus dipatuhi oleh karyawan.

b. Motivasi: komunikasi membantu perkembangan motivasi dengan menjelaskan kepada para karyawan apa yang harus dilakukan bagaimana mereka bekerja baik dan apa yang dapat dikerjakan untuk memperbaiki kinerja jika itu di bawah standar.

c. Pengungkapan emosional : bagi banyak karyawan kelompok kerja mereka merupakan sumber utama untuk interaksi sosial, komunikasi yang terjadi di dalam kelompok itu merupakan mekanisme fundamental dengan mana anggota-anggota menunjukkan kekecewaan dan rasa puas mereka oleh karena itu komunikasi menyiarkan ungkapan emosional dari perasaan dan pemenuhan kebutuhan sosial.

d. Informasi: komunikasi memberikan informasi yang diperlukan individu dan kelompok untuk mengambil keputusan dengan meneruskan data guna mengenai dan menilai pilihan-pilihan alternatif

e. Sosialisasi.

f. Perdebatan dan diskusi.

g. Pendidikan.

h. Memajukan kebudayaan.

i. Hiburan. ${ }^{19}$

\section{Kesimpulan}

Peran guru sebagai administrator dalam proses pembelajaran cukup baik, hal ini ditunjukan dengan keseriusan setiap guru dalam mempersiapkan materi yang terkait kegiatan belajar rmngajar. Kemudian peran guru dalam desain pembelajaran saat kegiatan belajar mengajar cukup baik. Dimana guru berusaha untuk memberikan pemahaman kepada siswa dalam suatu masalah yang dibahas. Peran guru dalam menggunakan media sudah cukup baik, hal ini dibuktikan bahwa guru mampu mengoperasikan media pembelajaran tersebut. Peran guru sebagai evaluator dalam kegiatan belajar mengajar cukup baik. Dimana dalam kegiatan evaluasi tersebut guru memberikan hasilnya kepada siswa terhadap tugas yang siswa. Sehingga siswa akan terus brusaha memperbaiki belajar mereka.

\section{Daftar Pustaka}

\footnotetext{
17 Jalaludin Rakhmat, Psikologi Komunikasi, h. 45

${ }^{18}$ Onong Uchyana Effendy, Ilmu Komunikasi,: Sebuah Teori dan Praktek, h. 27-28

19 Ibid., h. 8
} 
Depag RI, Undang-Undang dan Peraturan Pemerintah RI Tentang Pendidikan, Jakarta: 2006.

Depdiknas, Kamus Besar Bahasa Indonesia, Jakarta: Balai Pustaka, 2001.

Djamarah, Syaiful Bahri, Guru dan Anak Didik Dalam Interaksi Edukatif, Jakarta: Rineka Cipta, 2005.

Effendy, Onong Uchyana, Ilmu Komunikasi Teori dan Praktek, Bandung: Rosdakarya, 1984.

Hadi, Sutrisno, Metodologi Reseach II , Yogya :Yayasan Pendidikan Fakultas Psikologi UGM, 1981

http://ventidanokarsa.blogspot.com/2009/05/peranan-teknologi-informasi dalam.html http://ventidanokarsa.blogspot.com/2009/05/perananteknologi-informasi-dalam.html Diakses pada tanggal 29 Januari 2011.

Moeloeng, Lexy J., Metodologi Penelitian Kualitatif, Bandung : PT Remaja Rosdakarya, 1997. Cet. ke-8.

Munadi, Yudhi, Media Pembelajaran Sebuah Pendekatan Baru, Jakarta: Gaung Persada Press, 2008.

Nata, Abudin, Manajemen Pendidikan: Mengatasi Kelemahan Pendidikan Islam di Indonesia, Jakarta: Prenada, 2003.

Nata, Abudin, Perspektif Islam Tentang Pola Hubungan Guru-Murid Study Pemikiran Tasawuf al-Ghazali, Jakarta: PT Raja Grafindo Persada, 2001.

Rakhmat, Jalaludin, Psikologi Komunikasi, Bandung: Rosdakarya, 1985.

Rasyad, Aminuddin, Teori Belajar dan Pembelajaan, Jakarta : Uhamka Press \& Yayasan Pep -Ex 8, 2006. Cet. Ke-6.

Surya, Muhammad, Makalah dalam Seminar "Pemanfaatan Teknologi Informasi dan Komunikasi untuk Pendidikan Jarak Jauh dalam Rangka Peningkatan Mutu Pembelajaran", diselenggarakan oleh Pustekkom Depdiknas, tanggal 12 Desember 2006 di Jakarta.

Syafrudin dan Basyirudin Usman, Guru Profesional dan Implementasi Kurikulum, Jakarta: Ciputat Pres, 2002.

Syukur, Fatah, Teknologi Pendidikan, Semarang: Rasail, 2008.

Tasmara, Toto, Komunikasi Dakwah, Jakarta: Media Pratama, 2005.

Uno, Hamzah B., Profesi Kependidikan: Problema, Solusi, dan Reformasi Pendidikan di Indonesia, Jakarta: Bumi Aksara, 2009.

Warsita, Bambang, Teknologi Pembelajaran: Landasan dan Aplikasinya, Jakarta: Rineka Cipta, 2009. 